\title{
Effects of Nitrogen on Ramie (Boehmeria nivea) Hybrid and Its Parents Grown under Field Conditions
}

\author{
Chengjian Huang ${ }^{1,2}$, Gang $\mathrm{Wei}^{2}$, Zizi Luo ${ }^{3}$, Jianjun $\mathrm{Xu}^{2}$, Siyi Zhao ${ }^{2}$, Longchang Wang ${ }^{4} \&$ Yucheng Jie $^{1}$ \\ ${ }^{1}$ Institute of Ramie, Hunan Agricultural University, Changsha, China \\ ${ }^{2}$ Dazhou Institute of Agricultural Sciences, Dazhou, China \\ ${ }^{3}$ Chongqing Institute of Meteorological Sciences, Chongqing, China \\ ${ }^{4}$ College of Agronomy and Biotechnology, Southwest University, Chongqing, China \\ Correspondence: Yucheng Jie, Institute of Ramie, Hunan Agricultural University, 1 Nongda Rd, Furong District, \\ Changsha 410128, Hunan Province, China. Tel: 86-731-8467-3926. Fax: 86-731-8467-3926. E-mail: \\ ibfcjyc@vip.sina.com
}

Received: September 16, 2014 Accepted: October 8, 2014 Online Published: November 15, 2014

doi:10.5539/jas.v6n12p230

URL: http://dx.doi.org/10.5539/jas.v6n12p230

\begin{abstract}
Excessive nitrogen supply has resulted in environmentally negative impacts. In order to select and develop $\mathrm{N}$-efficient ramie cultivars in increased $\mathrm{N}$ application environments, the morphological, physiological and biochemical responses of a ramie hybridization line (Chuanzhu 11) and its conventional parents (C9451 and R79-20) to $\mathrm{N}$ fertilizer were investigated under rain-fed conditions during three consecutive growing seasons. Two contrasting nitrogen levels (low nitrogen, LN: $20 \mathrm{~kg} \mathrm{ha}^{-2}$; high nitrogen, $\mathrm{HN}: 120 \mathrm{~kg} \mathrm{ha}^{-2}$ ) were used. Results indicated that high $\mathrm{N}$ substantially promoted the growth of ramie plants and led to remarkable increase in fiber yield in all cultivars during the three growing seasons. Such increase was also recorded in net photosynthesis, transpiration rate and stomatal conductance, as well as chlorophylls and carotenoids. However, high $\mathrm{N}$ supply caused no alteration or increase in intercellular $\mathrm{CO}_{2}\left(\mathrm{C}_{\mathrm{i}}\right)$ and $\mathrm{C}_{\mathrm{i}} / \mathrm{C}_{\mathrm{a}}\left(\right.$ ambient $\left.\mathrm{CO}_{2}\right)$ ratio, depending on species. Moreover, high $\mathrm{N}$ application significantly improved soluble protein and proline content while it reduced malondialdehyde content. The activities of superoxide dismutase and catalase also elevated, whereas peroxidase activity decreased by high $\mathrm{N}$ application in all cultivars. Furthermore, hybrid cultivar Chuanzhu 11 exhibited better performance as compared to its parents C9451 and H7920 due to improved growth, fiber yield, leaf gas exchange traits and enzymatic and non-enzymatic antioxidant systems under high $\mathrm{N}$ supply conditions. In conclusion, ramie hybrid cultivar Chuanzhu 11 was more efficient to absorb and utilize high levels of N. This meets the need for uptake and utilization of high concentration of $\mathrm{N}$ in increased $\mathrm{N}$ fertilizer environments.
\end{abstract}

Keywords: ramie, chlorophyll contents, gas exchange, antioxidant enzymes, fiber yield, nitrogen

\section{Introduction}

While nitrogen (N) fertilizer is an important way to increase crop yields, high $\mathrm{N}$ application rates in China is becoming common and getting severe. High $\mathrm{N}$ supply not only increases the famer's cost, but also has resulted in environmentally negative impacts such as global warming (from increasing atmospheric $\mathrm{N}_{2} \mathrm{O}$ ), pollution of ground water with nitrate, eutrophication of surface water, soil acidification (from redeposited $\mathrm{NH}_{3}$ ) and soil secondary salinization (Goulding, 2004; Hirel et al., 2007; Cao et al., 2009; Yang et al., 2010). Despite the detrimental impact on the biosphere, the use of $\mathrm{N}$ fertilizer in agriculture has provided a food supply sufficient for both animal and human consumption (Cassman, 1999). Therefore, when excessive $\mathrm{N}$ fertilization cannot be totally avoided, it is important to breed and grow species or genotypes that are able to absorb, accumulate and utilize high concentrations of $\mathrm{N}$ (Hirel et al., 2007).

Optimal nitrogen nutrition is fundamental to the growth and productivity of plants. Nitrogen deficiency causes a reduction in growth rate, whereas excessive $\mathrm{N}$ supply has a direct inhibitory effect on growth and yield in many plant species (Sánchez et al., 2004; Cao et al., 2009). N limitation may lower net photosynthesis by decreasing photosynthetic pigment contents (Zhao et al., 2005; Yao \& Liu, 2006; Cabrera-Bosquet et al., 2009). Further increased nitrogen fertilizer does not increase photosynthetic pigments and photosynthesis (Correia et al., 2005; Dordas \& Sioulas, 2008; Boussadia et al., 2010). The effect of $\mathrm{N}$ levels on photosynthesis is manifested in 
differences in the stomatal conductance and the intercellular carbon dioxide $\left(\mathrm{CO}_{2}\right)$, but the results are not consistent between different plant species (Zhang et al., 2013). N limitation influences photosynthetic rate through non-stomatal factors in many plant species such as soybean (Zhang et al., 2013), maize (Correia et al., 2005) and safflower (Dordas \& Sioulas, 2008), whereas, in a few species reduction in rates of photosynthesis under conditions of nitrogen limitation are attributed to stomatal factors (Zhao et al., 2005; Yao \& Liu, 2006).

$\mathrm{N}$ deficiency is among the several environmental factors that can reduce the activity of carboxylation and increase the production of reactive oxygen species (ROS) (Huang et al., 2004; Pompelli et al, 2010; Rubio-Wilhelmi et al., 2011). ROS caused lipid peroxidation and disturbs protective mechanism based on antioxidant enzymes and non-enzymatic antioxidants. A higher $\mathrm{N}$ availability may increase the protection against oxidative stress and reduces malondialdehyde (MDA) content (Ramalho et al., 1998; Zhang et al., 2007; Pompelli et al, 2010). Nonetheless, when plants are exposed to increased $\mathrm{N}$ fertilizer, protective enzymes such as superoxide dismutase (SOD), peroxidase (POD) and catalase (CAT) exhibit complex patterns, the results are often conflicting in different plant species (Ramalho et al., 1998; Zhang et al., 2007; Liu et al., 2008). This suggested that changes in the activities of protective enzymes under higher $\mathrm{N}$ conditions are associated with plant genotypes.

Ramie (Boehmeria nivea L.), or 'Chinagrass', is a perennial herbaceous plant of the Urticaceae family. It is widely cultivated as a natural fiber crop due to its unique quality, as well as feedstuff for $25 \%$ of protein in the stems and leaves in China and other adjoining Asian countries. It can be harvested three times a year in the Yangtze River Basin which is the major production area of China. Conventionally, ramie reproduces by asexual means with vegetative organs, which not only requires tremendously intensive labor work, but also provides a source of habitat for pest and harbors disease. Recently, ramie can reproduce with seeds by sexual means. Hybrid ramie crop come from $F_{1}$ seeds of cross between two genetically dissimilar parents. Compared to the conventional varieties ramie hybrids have the potential of fiber yielding $20 \%-30 \%$.

$\mathrm{N}$ is primary nutrient for ramie growth and fiber yield (Cabangbang, 1978; Tatar et al., 2010). Ramie generally needs high amount of $\mathrm{N}$ fertilization to ensure high yields (Cabangbang, 1978; Maity et al., 2007; Tatar et al., 2010; Patra \& Sinha, 2012). Although it is well known that there is some genetic variability in N uptake (Cabangbang, 1978; Maity et al., 2007), the physiological and biochemical basis for such variability has not been thoroughly investigated. Understanding the mechanism would help in the selection and development of $\mathrm{N}$-efficient ramie cultivars in increased $\mathrm{N}$ fertilizer environments. The objective of this study was to explore the effects of nitrogen on growth, yield, gas exchange traits, chlorophyll contents, soluble protein, MDA, proline and the activities of antioxidant enzymes in a ramie hybrid and its conventional parents.

\section{Method}

\subsection{Experimental Site and Experimental Design}

The field experiments were carried out at College of Agronomy and Biotechnology, Southwest University, Chongqing, China, following a wheat crop, during June-December 2012 and March-July 2013. The experimental area lies between latitude $29^{\circ} 49^{\prime} 32^{\prime \prime} \mathrm{N}$, longitude $106^{\circ} 26^{\prime} 02^{\prime \prime} \mathrm{E}$ and altitude $220 \mathrm{~m}$. The soil of this site is typical purple soil containing organic matter $19.36 \mathrm{~g} \mathrm{~kg}^{-1}$, total nitrogen $1.103 \mathrm{~g} \mathrm{~kg}^{-1}$, total phosphorus $0.291 \mathrm{~g} \mathrm{~kg}^{-1}$, total potassium $24.11 \mathrm{~g} \mathrm{~kg}^{-1}$, alkali-hydro nitrogen concentration $200.5 \mathrm{mg} \mathrm{kg}^{-1}$, available phosphorus $19.41 \mathrm{mg} \mathrm{kg}^{-1}$, readily-available potassium $171.4 \mathrm{mg} \mathrm{kg}^{-1}$ and $\mathrm{pH} 6.25$.

Weather data including rainfall, sunshine hours and temperatures were obtained from Chongqing Institute of Meteorological Sciences. These data were recorded by daily and were reported as mean monthly data for the 2 years that the study was conducted (Table 1). 
Table 1. Monthly average air temperatures, rainfall and sunshine hours for 2012 and 2013 years and the 30-year average at Chongqing, China

\begin{tabular}{|c|c|c|c|c|c|c|c|c|c|}
\hline \multirow[b]{2}{*}{ Month } & \multicolumn{3}{|c|}{2012} & \multicolumn{3}{|c|}{2013} & \multicolumn{3}{|c|}{30 -years } \\
\hline & $\begin{array}{c}\text { Average } \\
\text { temperatures } \\
\left({ }^{\circ} \mathrm{C}\right)\end{array}$ & $\begin{array}{c}\text { Rainfall } \\
(\mathrm{mm})\end{array}$ & $\begin{array}{c}\text { Sunshine } \\
\text { hours } \\
\text { (hour) }\end{array}$ & $\begin{array}{c}\text { Average } \\
\text { temperatures } \\
\left({ }^{\circ} \mathrm{C}\right)\end{array}$ & $\begin{array}{c}\text { Rainfall } \\
(\mathrm{mm})\end{array}$ & $\begin{array}{c}\text { Sunshine } \\
\text { hours } \\
\text { (hour) }\end{array}$ & $\begin{array}{c}\text { Average } \\
\text { temperatures } \\
\left({ }^{\circ} \mathrm{C}\right)\end{array}$ & $\begin{array}{c}\text { Rainfall } \\
(\mathrm{mm})\end{array}$ & $\begin{array}{c}\text { Sunshine } \\
\text { Hours } \\
\text { (hour) }\end{array}$ \\
\hline January & 7.2 & 26.5 & 11.6 & 7.8 & 6.0 & 52.9 & 7.7 & 17.7 & 25.5 \\
\hline February & 8.7 & 12.9 & 14.2 & 11.6 & 17.5 & 49.0 & 9.8 & 21.1 & 31.2 \\
\hline March & 13.6 & 25.4 & 81.0 & 17.6 & 4.9 & 125.6 & 13.6 & 43.4 & 70.7 \\
\hline April & 19.7 & 56.2 & 114.2 & 20.1 & 91.7 & 154.6 & 18.4 & 100.6 & 99.5 \\
\hline May & 22.5 & 230.3 & 54.5 & 22.3 & 306.2 & 115.9 & 22.5 & 148.6 & 117.6 \\
\hline June & 24.3 & 164.6 & 47.2 & 27.7 & 278.7 & 182.5 & 25.0 & 196.8 & 102.2 \\
\hline July & 28.0 & 113.1 & 144.1 & 30.6 & 88.9 & 213.5 & 28.2 & 199.4 & 165.7 \\
\hline August & 29.1 & 97.1 & 182.6 & 29.5 & 103 & 213.5 & 28.1 & 145.7 & 170.9 \\
\hline Semptember & 22.8 & 145.9 & 87.0 & 23.0 & 170.7 & 79.6 & 23.9 & 124.7 & 109.2 \\
\hline October & 17.9 & 72.3 & 43.9 & 19.1 & 84.1 & 85.1 & 18.5 & 87.8 & 53.5 \\
\hline November & 13.1 & 25.7 & 40.0 & 14.1 & 52.5 & 27.8 & 14.0 & 47.3 & 41.6 \\
\hline December & 9.1 & 8.1 & 38.4 & 10.2 & 7.2 & 20.3 & 9.0 & 23.3 & 25.8 \\
\hline Total & & 978.1 & 858.7 & & 1211.4 & 1320.3 & & 1156.6 & 1013.4 \\
\hline
\end{tabular}

The ramie (Boehmeria nivea L.) hybrid Chuanzhu 11 was a two-line hybrid ramie variety developed by good male sterile line C9451 and restorer line R79-20. It is the commercial ramie crop from $\mathrm{F}_{1}$ seeds of cross between C9451 and R79-20. Its parents C9451 and R79-20 were conventional cultivars reproduced by asexual means with rhizomes. The hybrid is genetically stable and shows no separation phenomenon and was authorized in 2007 in China. It has been widely cultivated in the Yangtze River Basin including Sichan, Chongqing, Guizhou, JiangXi, Hunan and Hubei province in China. Chuanzhu 11, C9451 and R79-20 were obtained from Dazhou Institute of Agricultural Sciences, Sichuan, China, were used as test cultivars.

In spring 2012, seeds of hybrid ramie cultivar Chuanzhu 11 were sown in the nursery beds in the fields. The seedlings of C9451 and R79-20 were planted in previous autumn as rhizomes, regrowth started early in March after a dormancy of 4 months. On June 3, 2012 seedlings of cultivar Chuanzhu 11 (40 days old), C9451 and R79-20 were all transplanted into the fields, one plant a hole. The plant population density is 42000 plants $\mathrm{hm}^{-2}$. The plants spacing was $60 \mathrm{~cm}$ between rows and $40 \mathrm{~cm}$ within rows. The experimental plots were $3 \mathrm{~m} \times 6 \mathrm{~m}$ and consisted of five rows. The crops were differentiated by two nitrogen supply: the HN (high nitrogen) treatment and the LN (low nitrogen) treatment. The former was fertilized by applying $20 \mathrm{~kg} \mathrm{~N} \mathrm{hm}^{-2}$, while the latter by 120 $\mathrm{kg} \mathrm{N} \mathrm{hm}^{-2}$ [here after referred to as low $\mathrm{N}(\mathrm{LN})$ and high $\mathrm{N}(\mathrm{HN})$ plants, respectively]. In summer 2012, the soil was prepared by adding $67 \mathrm{~kg} \mathrm{hm}^{-2} \mathrm{NPK}$ compound fertilizer with $\mathrm{N}: 30 \%, \mathrm{P}_{2} \mathrm{O}_{5}: 5 \%, \mathrm{~K}_{2} \mathrm{O}: 5 \%$. High N treatments were imposed on young seedlings by applying $220 \mathrm{~kg} \mathrm{hm}^{-2}$ nitrogen as Urea (46\% N, China) on the 20 th day after transplanting. Planting arrangement in plots were patterned after those used by local farmers. Each treatment had three replicates in a randomized blocks design. Weeding was carried out manually throughout the growth period. The plants were cut on August 25, 2012. On August 26, 2012, hoeing was give manually and two nitrogen levels were treated after the previous cut. Urea $(46 \% \mathrm{~N}$, China) was used as nitrogen source. There was little weeding throughout the growth period. The plants were cut on December 4, 2012. After the cut, hoeing was give manually. In spring 2013, two nitrogen levels were treated as Urea ( $46 \%$ N, China) when the regrowth started late in February. Also, there was little weeding throughout the growth period. The plants were cut on July 4, 2013.

\subsection{Measurement of Growth and Yield Components}

Leaf area of ramie plants was measured with a leaf area meter (LI-3100, LI-COR, Lincoln, NE, USA). At harvest the growth and yield contributing characters were recorded from 20 randomly selected plants each plot and quantified to measure plant height, stem diameter, number of stems. Fresh stem bast were stripped from plants and 
measured for bast fresh weight. Fiber layer of fresh stem bast were separated and dried under sunlight and weighed to determine dry fiber weight. During summer 2012 and spring 2013 the rest of the plants (except for fiber) include leaf, leaf stalk, woody stem and residue of the fresh bast were oven dried for $72 \mathrm{~h}$ at $70{ }^{\circ} \mathrm{C}$ to determine shoot dry weight (equation 1). However, ramie plants blossom in autumn when day length was getting shorter, thus the dried fruits for $72 \mathrm{~h}$ at $70{ }^{\circ} \mathrm{C}$ were also calculated for shoot dry weight during autumn 2012 (equation 2).

(1) Shoot dry weight $=$ leaf dry weight + leaf stalk dry weight + stem dry weight + dry weight of residue of the fresh bast + dry fiber weight

(2) Shoot dry weight $=$ leaf dry weight + leaf stalk dry weight + stem dry weight + dry fruit + dry weight of residue of the fresh bast + dry fiber weight

At each harvesting time the fresh stem bast of the two central rows in the plots was stripped from plants. Then fiber layer of fresh stem bast was separated and dried under sunlight and weighed to determine crude fiber yield.

\subsection{Gas Exchange Measurements}

The net photosynthesis $(\mathrm{A})$, transpiration rate $(\mathrm{E})$, stomatal conductance $\left(\mathrm{g}_{\mathrm{s}}\right)$ and intercellular $\mathrm{CO}_{2}\left(\mathrm{C}_{\mathrm{i}}\right)$ were measured with a portable open-system infrared gas exchange analyzer based photosynthesis system (LI-6400, LI-COR, Lincoln, NE, USA) during 8:30-12:00 am. The 6- $7^{\text {th }}$ leaf from top were measured as described by Liu (2010) on the $40^{\text {th }}$ day after nitrogen treatment during summer 2012, and on the $50^{\text {th }}$ day during autumn 2012 and spring 2013, respectively. Fifteen leaves on the main stem per plot were selected for each treatment. Water use efficiency (WUE) was calculated as ratio of photosynthetic rate (A) to transpiration rate (E), while $\mathrm{C}_{\mathrm{i}} / \mathrm{C}_{\mathrm{a}}$ was calculated as ratio of intercellular $\mathrm{CO}_{2}\left(\mathrm{C}_{\mathrm{i}}\right)$ to ambient $\mathrm{CO}_{2}\left(\mathrm{C}_{\mathrm{a}}\right)$.

\subsection{Assay of Leaf Pigments, Soluble Protein, MDA, Proline and Antioxidant Enzyme Activity}

Ramie plants were sampled when and where the leaf gas exchange parameters were determined and divided into small pieces to assess photosynthetic pigments, MDA and proline. After washing, leaves were frozen in liquid $\mathrm{N}_{2}$ and stored at $-80{ }^{\circ} \mathrm{C}$ until biochemical analysis. Photosynthetic pigments, MDA and proline were determined using fresh leaf sample, while soluble protein and antioxidant enzyme activity were measured using frozen leaf sample. Chlorophyll $a(\mathrm{Chl} a)$, chlorophyll $b(\mathrm{Chl} b)$ and chlorophyll $a+b(\mathrm{Chl} a+b)$ were analyzed following the methods of Arnon (1949), while Car were assayed according to Lichtenthaler and Wellburn (1983). Proline content was measured using the method of Bates et al. (1973). MDA content was determined as described by De Vos et al. (1991).

$0.5 \mathrm{~g}$ leaf samples were ground in liquid nitrogen, adding $5 \mathrm{ml} 50 \mathrm{mM}$ sodium phosphate buffer ( $\mathrm{pH}$ 7.0), which contains $1 \mathrm{mM}$ EDTA-Na $\mathrm{N}_{2}$ and $2 \%(\mathrm{w} / \mathrm{v})$ polyvinylpyrrolidine-40 (PVP-40). The homogenate was centrifuged at $12000 \mathrm{~g}$ for $20 \mathrm{~min}$ at $4{ }^{\circ} \mathrm{C}$. The supernatant was collected and used for proteins and antioxidant enzymes activity analysis. Soluble protein was measured with Bradford G-250 reagent (Bradford, 1976), using bovine serum albumin (BSA) as standard.

The POD (EC 1.11.1.6) activity was measured according to the method of Upadhyaya et al. (1985). The activities of SOD (EC 1.15.1.1) and CAT (EC 1.11.1.7) were assayed by ready kits provided by Nanjing Jiancheng Bioengineering Institute, China, following the protocol mentioned with the detection kit. One unit of SOD activity was defined as the amount of enzyme required for $1 \mathrm{mg}$ tissue proteins in $1 \mathrm{ml}$ of a reaction mixture SOD inhibition rates to $50 \%$ as monitored at $550 \mathrm{~nm}$. One unit of CAT activity was defined as $1 \mathrm{mg}$ tissue proteins consumed $1 \mu \mathrm{mol} \mathrm{H}_{2} \mathrm{O}_{2}$ at $405 \mathrm{~nm} \mathrm{sec}^{-1}$.

\subsection{Statistical Analysis}

The experiment was arranged as $2 \times 3$ factorials ( $2 \mathrm{~N}$ sources and 3 Ramie genotypes) in a randomized blocks design with three replicates. Analysis of variance (ANOVA) was performed separately in each season according to the randomized-block design to identify significant differences among the cultivars. The mean values obtained were compared by Newman-Keuls tests, marked by letters, where the values sharing different letters are significantly different at $5 \%$ level by the SPSS 16.0 .

\section{Results}

\subsection{Growth and Yield}

A subsequent increase was observed in ramie growth in terms of leaf area index (LAI) and shoot dry weight from summer 2012 to spring 2013. However, the growth was noticeably affected by $\mathrm{N}$ treatments. High $\mathrm{N}$ treatments stimulated plant growth for all ramie cultivars from summer 2012 to spring 2013 (Figures 1A and 1B). During the three consecutive growing seasons high $\mathrm{N}$ application substantially increased LAI by an average of $18.53 \%$ 
for cultivar Chuanzhu 11, 16.23\% for C9451, 15.35\% for R79-20, respectively (Figure 1A). Similar increase in shoot dry weight per plant was an average of $21.79 \%$ in cultivar Chuanzhu $11,15.92 \%$ in cultivar C9451, $17.17 \%$ in cultivar R79-20, respectively during the three growing seasons (Figure 1B).

A continuous increase was also detected in fiber yield, dry fiber weight, fresh bast weight and number of efficient stems per plant from summer 2012 to spring 2013 (Figures 1C, 1D, 1E and 2A). N fertilization noticeably improved fiber yield in all cultivars during the whole growth period (Figure 1C). This increase was an average of $26.86 \%$ in Chuanzhu $11,17.22 \%$ in C9451, $18.53 \%$ in R79-20 with high $\mathrm{N}$ application compared to the low $\mathrm{N}$ controls, respectively during the three growing seasons (Figure 1C). Dry fiber weight and fresh bast weight per plant were also enhanced by an average of $31.69 \%$ and $24.35 \%$ for Chuanzhu $11,24.74 \%$ and 21.05 $\%$ for C9451, 25.68\% and $18.44 \%$ for R79-20, respectively during the three growing seasons (Figures 1D and 1E). Likewise, same pattern of increase in yield components was followed for plant height (Figure 1F), number of efficient stems (Figure 2A), percentage of number of efficient stems to total stems (Figure 2B) and stem diameter (Figure 2C) from summer 2012 to spring 2013.

Nonetheless, higher increase in growth, fiber yield and yield components due to high $\mathrm{N}$ supply was observed for the hybrid compared to its conventional parents. Higher LAI, plant height, stem diameter, shoot dry weight, fresh bast weight, fiber weight and fiber yield were always recorded in the hybrid than its parents under both low $\mathrm{N}$ and high N supply conditions during 2012-2013 growing seasons (Figures 1 and 2). This indicated that ramie hybrids were more vigorous and productive than conventional ramie cultivars under both high $\mathrm{N}$ and low $\mathrm{N}$ supply conditions.

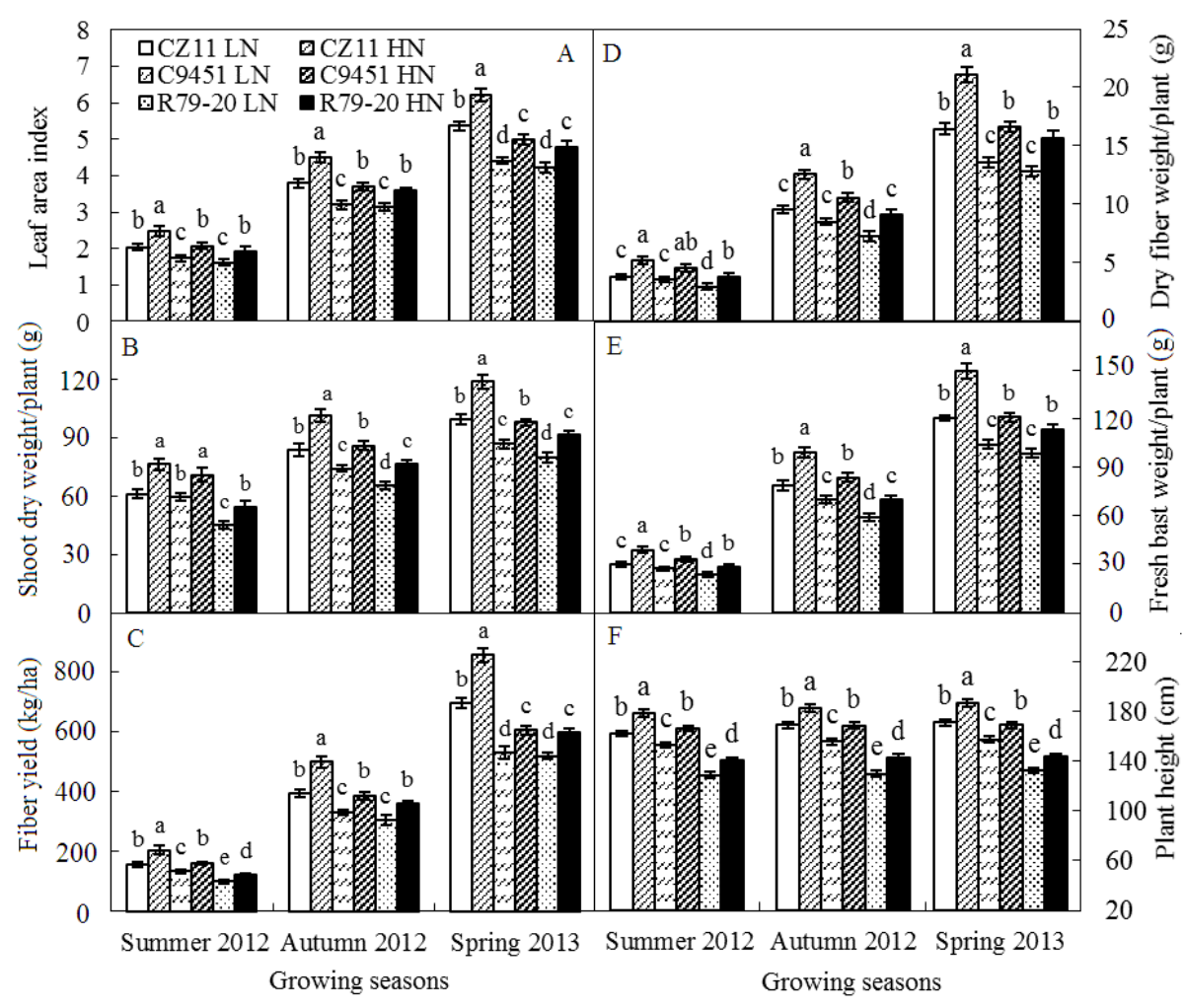

Figure 1. Leaf area index (A), shoot dry weight per plant (B), fiber yield (C), dry fiber weight per plant (D), fresh bast weight per plant $(\mathrm{E})$ and plant height $(\mathrm{F})$ in three ramie cultivars grown under two nitrogen levels during 2012-2013 growing seasons. LN: low nitrogen, $20 \mathrm{~kg} \mathrm{hm}^{-2}$; HN: high nitrogen, $120 \mathrm{~kg} \mathrm{hm}^{-2}$; CZ11: Chuanzhu 11. Different letters indicate significant difference between treatments at $p<0.05$ according to Newman-Keuls test 


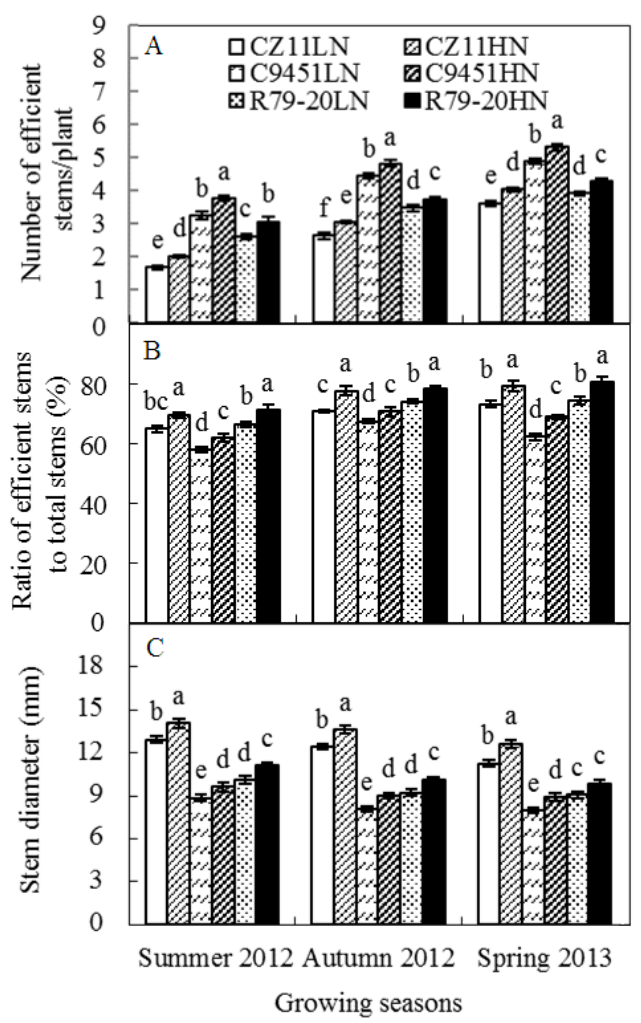

Figure 2. Number of efficient stems per plant (A), ratio of efficient stems to total stems (B) and stem diameter (C) in three ramie cultivars grown under two nitrogen levels during 2012-2013 growing seasons. LN: low nitrogen, $20 \mathrm{~kg} \mathrm{hm}^{-2}$; HN: high nitrogen, $120 \mathrm{~kg} \mathrm{hm}^{-2}$; CZ11: Chuanzhu 11. Different letters indicate significant difference between treatments at $\mathrm{p}<0.05$ according to Newman-Keuls test

\subsection{Gas Exchange}

$\mathrm{A}, \mathrm{E}$ and $\mathrm{g}_{\mathrm{s}}$ in all cultivars were enhanced by high $\mathrm{N}$ treatments in various degrees in comparison to their respective controls from summer 2012 to spring 2013 (Figure 3). High N application increased A, E and $\mathrm{g}_{\mathrm{s}}$ by an average of $12.23 \%, 10.75 \%$ and $11.98 \%$ in Chuanzhu 11 , whereas, elevated these traits by an average of $9.57 \%$, $8.60 \%$ and $9.07 \%$ in C9451, by an average of $9.79 \%, 8.64 \%$ and $9.37 \%$ in R79-20, respectively during the three growing seasons (Figures 3A, 3B and $3 \mathrm{C}$ ). The increase in $\mathrm{A}, \mathrm{E}$ and $\mathrm{g}_{\mathrm{s}}$ due to high $\mathrm{N}$ supply was higher in the hybrid than in its parents. Also, higher rates of $\mathrm{A}, \mathrm{E}$ and $\mathrm{g}_{\mathrm{s}}$ were observed in the hybrid than in its parents in both high $\mathrm{N}$ and low $\mathrm{N}$ treated plants during the whole growth period, suggesting that the hybrid was more efficient in photosynthetic capacity than its conventional parents. However, there was no difference in WUE between high $\mathrm{N}$ and Low $\mathrm{N}$ treatments in all cultivars during the three growing seasons (Figure 3D).

Concerning $C_{i}$, high $\mathrm{N}$ supply significantly increased $C_{i}$ for cultivar C9451, while no notable difference was observed in the other two species between the two N levels from summer 2012 to spring 2013 (Figures 3D and $3 \mathrm{E}$ ). Similar trend was also detected in $\mathrm{C}_{\mathrm{i}} / \mathrm{C}_{\mathrm{a}}$ ratio (Figure $3 \mathrm{~F}$ ). This showed that increase in rates of photosynthesis in cultivar Chuanzhu 11 and R79-20 by high $\mathrm{N}$ treatments was attributed to non stomatal factors, while in cultivar C9451 to stomatal factors. 


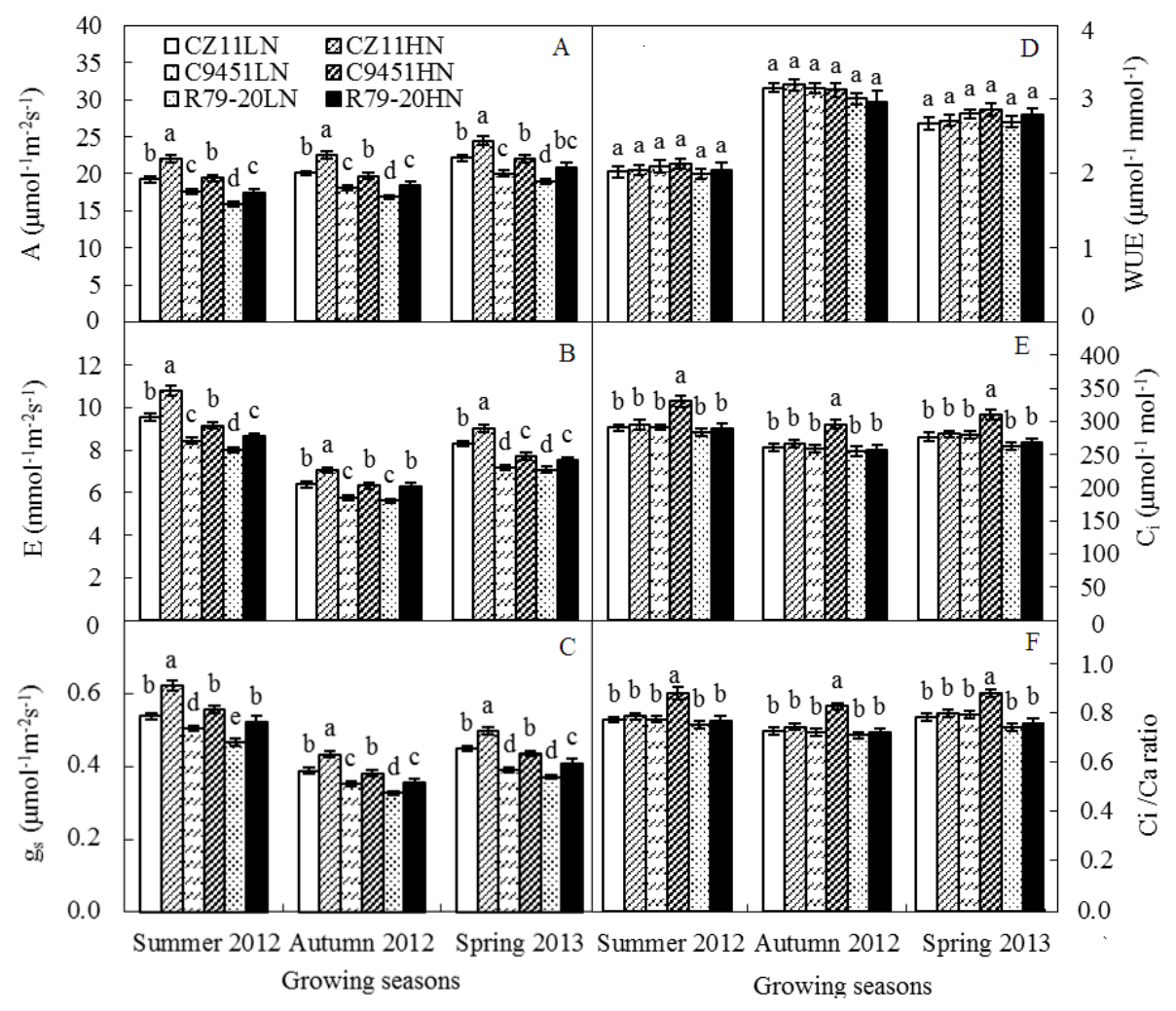

Figure 3. Net photosynthesis (A) (A), transpiration rate (E) (B), stamatal conductance $\left(\mathrm{g}_{\mathrm{s}}\right)(\mathrm{C})$, water use efficiency (WUE) (D), intercellular $\mathrm{CO}_{2}\left(\mathrm{C}_{\mathrm{i}}\right)(\mathrm{E}), \mathrm{C}_{\mathrm{i}} / \mathrm{C}_{\mathrm{a}}\left(\mathrm{C}_{\mathrm{a}}\right.$ : ambient $\left.\mathrm{CO}_{2}\right)$ ratio $(\mathrm{F})$ in three ramie cultivars grown under two nitrogen levels during 2012-2013 growing seasons. LN: low nitrogen, $20 \mathrm{~kg} \mathrm{hm}^{-2}$; HN: high nitrogen, $120 \mathrm{~kg} \mathrm{hm}^{-2}$; CZ11: Chuanzhu 11. Different letters indicate significant difference between treatments at $\mathrm{p}<0.05$ according to Newman-Keuls test

\subsection{Photosynthetic Pigments}

Chlorophyll contents were also improved by high $\mathrm{N}$ treatments in all cultivars during the three growing seasons (Figure 4). The dramatic increase in $\mathrm{Chl} a, \mathrm{Chl} b$, Chl $a+\mathrm{b}$ and Car was observed during summer 2012, with greater increase in $\mathrm{Chl} b$ than $\mathrm{Chl} a$, which resulted in decreased $\mathrm{Chl} a / b$ ratio for all species (Figures 4A, 4B, 4C, 4D and 4E). Nonetheless, Chuanzhu 11 and C9451 exhibited comparatively higher Chl $a$, Chl $b$, Chl $a+\mathrm{b}$ and Car than H79-20 during summer 2012 and spring 2013, while no difference was found in chlorophyll contents among the cultivars during autumn 2012 (Figures 4A, 4B, 4C and 4D).

$\mathrm{Chl} a / b$ ratio significantly decreased under high $\mathrm{N}$ conditions during summer 2012, whereas it was not affected by high N application during autumn 2012 and spring 2013 (Figure 4E). Also, there was no difference in Chl $a+$ $b /$ Car ratio neither between nitrogen levels nor between cultivars during the three consecutive growing seasons (Figure 4F). 


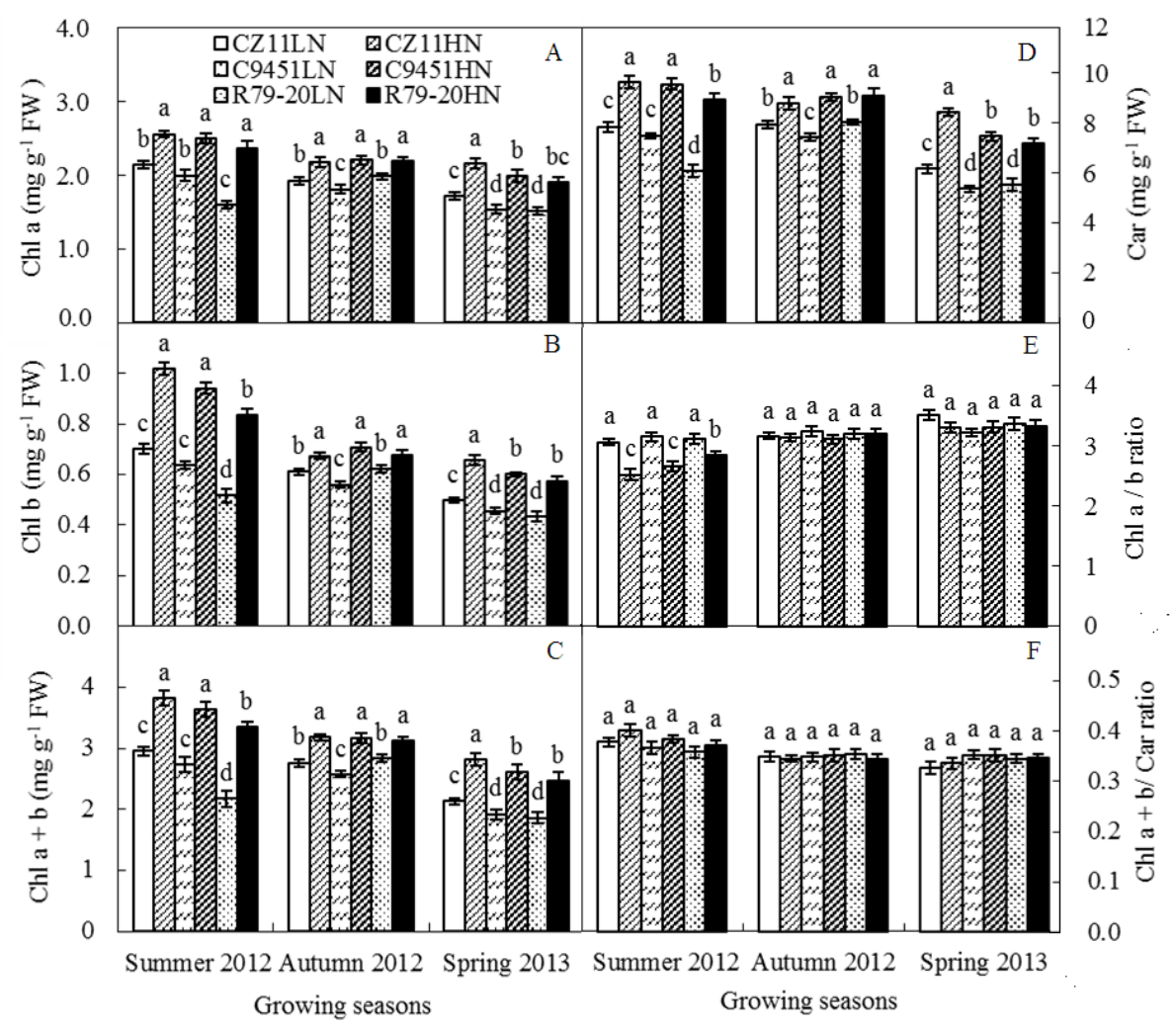

Figure 4. Chl $a$ (A), Chl $b$ (B), Chl $a+b$ (C), carotenoids (Car) (D), Chl $a / b$ ratio, Chl $a+b /$ Car ratio in three ramie cultivars grown under two nitrogen levels during 2012-2013 growing seasons. LN: low nitrogen, $20 \mathrm{~kg}$ $\mathrm{hm}^{-2}$; HN: high nitrogen, $120 \mathrm{~kg} \mathrm{hm}^{-2} ; \mathrm{CZ11}$ : Chuanzhu 11. Different letters indicate significant difference between treatments at $\mathrm{p}<0.05$ according to Newman-Keuls test

\subsection{Soluble Protein, Proline and Malondialdehyde (MDA)}

High $\mathrm{N}$ application significantly stimulated the accumulation of soluble protein and leaf proline, while it reduced MDA content in all ramie cultivars from summer 2012 to spring 2013 (Figures 5A, 5B and 5C). Considerable accumulation in soluble protein due to high $\mathrm{N}$ fertilizer was observed in the first growing season, whereas this accumulation in proline was detected during the second and third growing seasons. Nonetheless, Chuanzhu 11 accumulated relatively higher soluble protein and proline during the whole growth period (Figures 5A and 5B). The response of Chuanzhu 11 to high $\mathrm{N}$ application in proline and lipid peroxidation was much like that of R79-20 (Figures 5B and 5C).

\subsection{Antioxidant Enzyme Activity}

The activities of SOD and CAT were substantially enhanced by high N supply during the whole growth period, with higher increase and high rates in Chuanzhu 11 and R79-20 for each growing season (Figures 5A and 5C). And the response of Chuanzhu 11 to high $\mathrm{N}$ rates in SOD and CAT activity was also like that of R79-20. In contrast, POD activity was significantly decreased by high $\mathrm{N}$ fertilizer in all species in comparison to their low $\mathrm{N}$ controls. Nonetheless, higher POD activity was always documented in Chuanzhu 11 than in its parents under both low $\mathrm{N}$ and high $\mathrm{N}$ conditions during the three growing seasons (Figure 5B). 


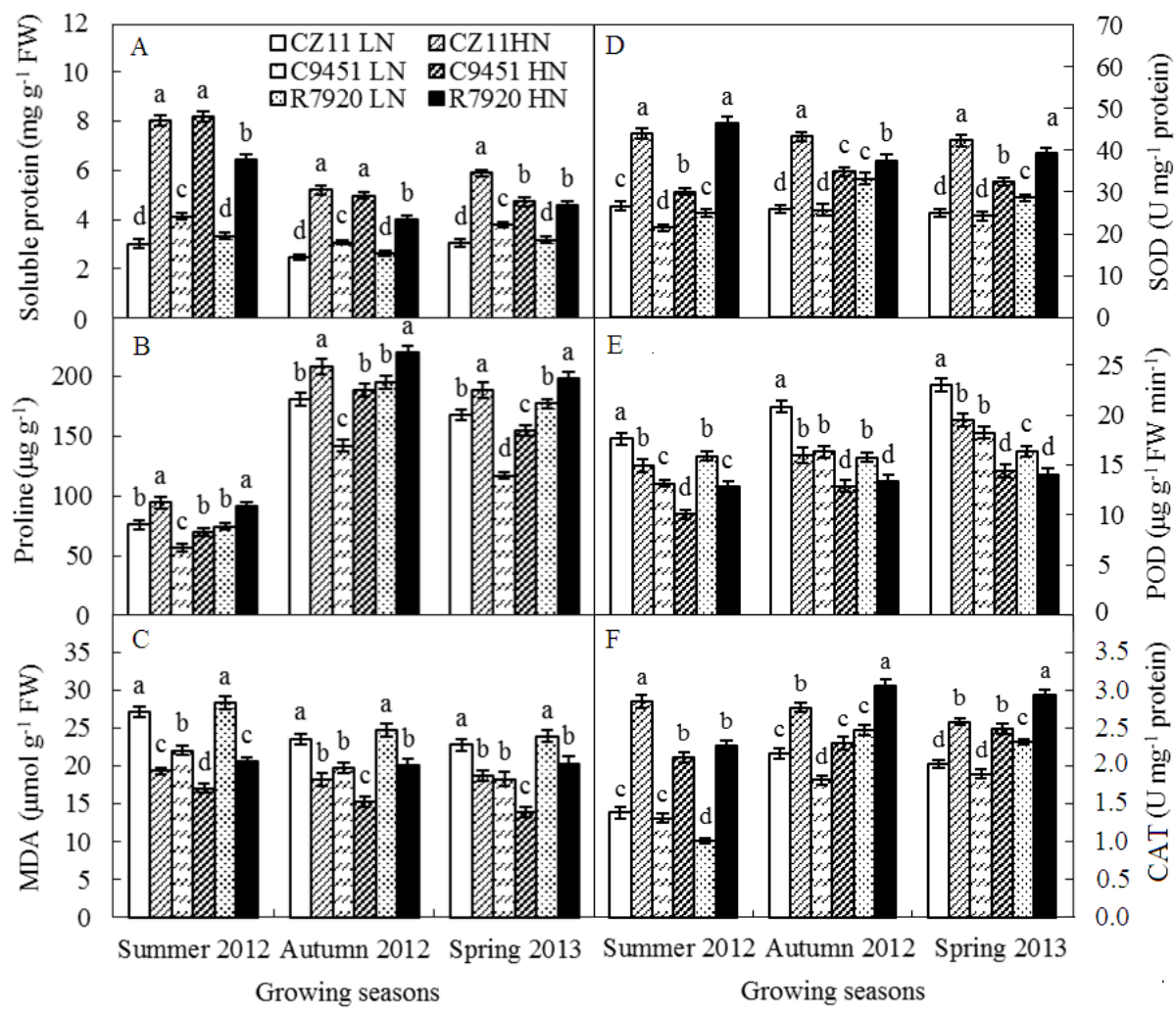

Figure 5. Soluble protein (A), proline (B), malondialdehyde (MDA) (C), SOD- superoxide dismutase (D), PODperoxidase $(\mathrm{E})$ and CAT-catalase $(\mathrm{F})$ in three ramie cultivars grown under two nitrogen levels during 2012-2013 growing seasons. LN: low nitrogen, $20 \mathrm{~kg} \mathrm{hm}^{-2}$; HN: high nitrogen, $120 \mathrm{~kg} \mathrm{hm}^{-2}$; CZ11: Chuanzhu 11. Different

letters indicate significant difference between treatments at $\mathrm{p}<0.05$ according to Newman-Keuls test

\section{Dicussion}

The management of the amount of $\mathrm{N}$ in the nutrient solutions of crops is a complex and important part of successful crop production system and sustainable progress. Nitrogen deficiency is a major limiting factor to plant growth and yield, increasing nitrogen fertilization level can obviously promoted the growth and crop yield (Zhao et al., 2005; Dordas \& Sioulas, 2008; Liu et al., 2008; Zhang et al., 2013 ). In the present study, N supply accelerated some growth parameters of LAI, number of efficient stems, plant height, stem diameter, bast fresh weight, dry fiber weight and shoot dry weight, subsequently fiber yield in all cultivars during 2012-2013 growing seasons. Similar results were also reported in previous publications (Tatar et al., 2010; Patra \& Sinha, 2012). The increase in growth and fiber yield by high $\mathrm{N}$ application in ramie plants might be attributed to improved leaf gas exchange properties. Although high $\mathrm{N}$ supply noticeably improved $\mathrm{A}, \mathrm{E}$ and $\mathrm{g}_{\mathrm{s}}$ in all ramie cultivars, hybrid cultivar Chuanzhu 11 demonstrated superior photosynthetic capacity to high $\mathrm{N}$ fertilization due to greater increase and higher rates in A, E and $g_{s}$ than its parents C9451 and R79-20. This helped to accumulate more dry matter, as measured by shoot dry weight per plant, and led to higher growth and fiber yield in the hybrid cultivar. Foulkes et al. (2009) and Kamkar et al. (2011) found that there is genetic diversity in N-use efficiency among crops, even species and cultivars of the same crop under contrasting conditions of high and low $\mathrm{N}$ input supply. Sattelmacher et al. (1994) reported genotypic variation in N-efficiency is attributed to high $\mathrm{N}$-uptake and/or high $\mathrm{N}$-utilization. Thus, it is reasonable to suggest a more efficient uptake and use of $\mathrm{N}$ fertilizer by hybrid cultivar Chuanzhu 11than by its conventional parent C9451 and R79-20 at high N levels.

Nitrogen is a fundamental constituent of many leaf cell components, particularly those components associated with the photosynthetic apparatus, including carboxylating enzymes and the chlorophyll and carotenoid-containing membrane proteins (Field \& Mooney, 1986). In addition, the synthesis of amino acids that is used for the synthesis of enzymes and proteins originates from the $\mathrm{N}$ taken up via the nitrate assimilatory pathway (Hirel \& Lea, 2001). Generally, the end products of the use and assimilation of the $\mathrm{NO}_{3}{ }^{-}$by the plants are basically amino acids and proteins (Barneix \& Causin, 1996). In our study, high $\mathrm{N}$ application exactly 
promoted the synthesis of photosynthetic pigments and soluble protein, led to higher Chl $a$, Chl $b, \mathrm{Chl} a+b, \mathrm{Car}$ and soluble protein in high $\mathrm{N}$ treated ramie plants. These results were in agreement with those found in maize (Correia et al., 2005) and sugar beet (Štajner et al., 1997). Nonetheless, the response of Chuanzhu 11 to high N levels in chlorophyll contents and soluble protein was much like of that in C9451, which indicated Chuanzhu 11 and C9451 were able to uptake and make use of more $\mathrm{N}$ in the plants than H79-20. Chlorophyll is one of the major chloroplast components for photosynthesis, and relative chlorophyll contents have a positive relationship with photosynthetic rate, while the photosynthetic enzyme Rubisco is the most abundant protein in plant leaves (Evans \& Seemann, 1989). Chlorophyll contents and soluble protein in Chuanzhu 11 were not always correlated with the high net photosynthesis at high $\mathrm{N}$ rates during the whole growth period. Similiar results were also reported in perennial wild Oryza and their interspecific hybrids (Zhao et al., 2008), as well as wheat and wheat hybrid (Yang et al., 2007). Higher photosynthetic rate in the $\mathrm{F}_{2}$ populations in the wild Oryza than their parents was associated with high leaf $\mathrm{N}$ content and high stomatal conductance (Zhao et al., 2008), while in wheat hybrid higher $\mathrm{CO}_{2}$ assimilation rate was mainly the result of both higher activity of Rubisco and higher PSII efficiency relative to its parents (Yang et al., 2007). Our results showed that higher net photosynthesis in the hybrid than its parents under high $\mathrm{N}$ conditions might be ascribed to higher chlorophyll and proteins, as well as higher antioxidants (Car, proline) and ROS scavenging enzymes (SOD, POD and CAT). Nonetheless, more research is needed on the activity of photosynthesis in ramie hybrid and its parents under high $\mathrm{N}$ conditions.

Environmental abiotic stresses lead to the overproduction of reactive oxygen species (ROS) in plants which are highly reactive and toxic. Plants possess an enzymatic and non-enzymatic antioxidant system including low-molecular mass antioxidants (Car, proline) and ROS scavenging enzymes (SOD, POD and CAT). Car and proline are effective quenchers of ${ }^{1} \mathrm{O}_{2}$ and $\mathrm{OH}^{-}$, while SOD can catalyze $\mathrm{O}_{2}^{-}$to $\mathrm{H}_{2} \mathrm{O}_{2}, \mathrm{H}_{2} \mathrm{O}_{2}$ is eliminated by POD and CAT in higher plants (Gill \& Tuteja, 2010). $\mathrm{N}$ deficiency in plants is also regarded as an abiotic stresses and can induce the formation of ROS leading to lipid peroxidation (analyzed through MDA accumulation) (Huang et al., 2004; Pompelli et al., 2010; Rubio-Wilhelmi et al., 2011). Increased N concentrations could improved oxidative stress defence ability and protects plants against photodamage by modifying enzymatic and non-enzymatic antioxidant systems, thus enhanced oxidative stress tolerance and reduced MDA content (Yao \& Liu, 2006; Zhang et al., 2007; Liu et al., 2008; Pompelli et al., 2010). In our study, proline and Car content noticeably enhanced, SOD and CAT activities also improved while POD activity decreased in ramie plants by high $\mathrm{N}$ fertilizer during the three growing seasons. The lower MDA content in HN plants was accompanied by higher contents of Car and proline, as well as higher activities of SOD and CAT, indicated that increased N could up-regulate protective Car, proline and detoxifying SOD and CAT enzymes in ramie plants. Such reports were also documented in maize (Zhang et al., 2007) and Mono Maple at high N levels (Yao \& Liu, 2006). On the other hand, the cooperation from antioxidants and antioxidant enzymes is essential for the scavenging of ROS in plant cells. The reduced MDA content under high $\mathrm{N}$ rates might be attributed to the cooperation of Car, proline, SOD, CAT and POD for the scavenging of ROS against photodamage in ramie plant cells.

In addition, the relationship between $\mathrm{N}$ availability and proline accumulation is usually positive (Andersen et al., 1995). Proline has been correlated with stress tolerance while high antioxidant enzymes are linked with oxidative stress tolerance. The hybrid cutivar Chuanzhu 11 possessed higher proline and Car, and higher activities of SOD, POD and CAT than its parents, which appeared to be one of the key mechanisms to maintain high dry matter and fiber yield of plants. Proline is also a N-storage compound (Ahmad \& Hellebust, 1988), increased N supply caused the stimulation of synthesis and accumulation of proline in ramie leaves. Such results are reported in the shoots of Mono Maple at high N rates (Yao \& Liu, 2006). Also, the enhanced activities of SOD and CAT in ramie plants might be associated with high $\mathrm{N}$ application, because $\mathrm{N}$ nutrition could improve synthesis and physiological activities of antioxidant enzymes (Sinclair \& Vadez, 2002; Yao \& Liu, 2006). Nonetheless, in this respect, some cultivars differed, especially Chuanzhu 11 and R79-20, which showed higher proline content and activities of SOD and CAT compared to C9451 under high N supply conditions, suggesting Chuanzhu 11 and R79-20 are able to absorb and utilize high concentrations of $N$ than C9451. Such variability could confer on some species or genotypes the ability to store greater quantities of $\mathrm{N}$ during periods of abundant $\mathrm{N}$ supply, thus avoiding losses into the soil (Hirel et al., 2007). This indicated the genotypic variability of crop $\mathrm{N}$ uptake capacity across a wide range of genotypes, thus allowing the selection of those having the greater capacity to accumulate an excess of $\mathrm{N}$.

Based on above reported evidence, amount of $\mathrm{N}$-fertilizer and cultivar selection had strong influence on ramie growth, fiber productivity, photosynthetic capacity, enzymatic and non-enzymatic antioxidant system. The relatively better performance of hybrid cultivar Chuanzhu 11 over its parents C9451 and H7920 might be attributed to improved growth, fiber yield, leaf gas exchange traits and enzymatic and non-enzymatic antioxidant 
systems at high $\mathrm{N}$ levels. This indicated that ramie hybrid cultivars were more efficient to absorb, accumulate and utilize high concentration of $\mathrm{N}$ than conventional cultivars. Nonetheless, high yield was probably associated with more efficient exploitation of nitrogen (Koutroubas et al., 2008). Also, inbreds seem to be inherently more limited than hybrids in their capacity for taking advantage of improved $\mathrm{N}$ growing conditions (D'Andrea et al., 2006, 2009). With respect to $\mathrm{N}$ uptake and utilization, the hybrid cultivar Chuanzhu 11 could be cultivated under high $\mathrm{N}$ affected soil due to the ability to uptake, store and make use of greater quantities of N, while C9451 and R79-20 can be optimal $\mathrm{N}$ tolerant materials for breeding programs.

\section{Conclusion}

The present study describes the morphological, physiological and biochemical mechanisms of nitrogen application on ramie hybrid Chuanhu 11 and its conventional parents C9451 and R79-20, which would help in the selection and development of $\mathrm{N}$-efficient ramie cultivars in increased $\mathrm{N}$ fertilizer environments. High $\mathrm{N}$ application led to significant increase in ramie growth and fiber yield, chlorophyll contents, gas exchange parameters, soluble protein and proline content, as well as the activities of SOD and CAT, where MDA content and POD activity were decreased under high $\mathrm{N}$ application conditions. The relatively better performance of hybrid cultivar Chuanzhu 11 as compared to its parents C9451 and H7920 might be attributed to improved growth, fiber yield, leaf gas exchange traits and enzymatic and non-enzymatic antioxidant systems under high $\mathrm{N}$ supply conditions. In conclusion, ramie hybrid cultivar Chuanzhu 11 was more efficient to absorb and utilize high concentrations of $\mathrm{N}$. This meets the need for uptake and utilization of high concentration of $\mathrm{N}$ in increased $\mathrm{N}$ fertilizer environments.

\section{Acknowledgements}

This research was supported by the national 'Twelfth 5-Year' scientific and technological support project (2012BAD20B05-04), the National Natural Science Foundation Program (31 371 704), scientific and technological project of Hunan (2010TP4004-1, 2010FJ2013 and 2012FJ4063). The authors highly thank Xiaojian Zhao for his kind help in the experimental field and laboratory assays.

\section{References}

Andersen, P. C., Brent, V. B., \& Ruseel, F. M. (1995). Water stress and nutrient solution mediated changes in water relations and amino acids, organic acids, and sugars in xylem fluid of Prunus salicina and and Lagerstroemia indica. Journal of the American Society for Horticultural Science, 120, 6-42.

Ahmad, I., \& Hellebust, J. A. (1988). The relationship between inorganic nitrogen metabolism and proline accumulation in osmoregulatory responses of two euryhaline microalgae. Plant Physiology, 88, 348-354. http://dx.doi.org/10.1104/pp.88.2.348

Arnon, D. T. (1949). Copper enzyme in isolated chloroplasts polyphenoloxidase in Beta vulgaris. Plant Physiology, 24, 1-15. http://dx.doi.org/10.1104/pp.24.1.1

Barneix, A. J., \& Causin, H. F. (1996). The central role of amino acids on nitrogen utilization and plant growth. Journal of Plant Physiology, 149, 358-362. http://dx.doi.org/10.1016/S0176-1617(96)80134-9

Bates, L. S., Waldren, R. P., \& Teare, I. D. (1973). Rapid determination of free proline for water-stress studies. Plant and Soil, 39, 205-207. http://dx.doi.org/10.1007/BF00018060

Boussadia, O., Steppe, K., Zgallai, H., Ben El-Hadj, S., Braham, M., Lemeur, R., \& Van Labeke, M. C. (2010). Effects of nitrogen deficiency on leaf photosynthesis, carbohydrate status and biomass production in two olive cultivars 'Meski' and 'Koroneiki'. Scientia Horticulturae, 123, 336-342. http://dx.doi.org/10.1016/j.scienta.2009.09.023

Bradford, M. N. (1976). A rapid and sensitive method for the quantitation of microgram quantities of protein utilizing the principle of protein-dye binding. Analytical Chemistry, 72, 248-254. http://dx.doi.org/10.1016/0003-2697(76)90527-3

Cabangbang, R. P. (1978). Fiber yield and agronomic characters of ramie as affected by plant density and fertilizer levels. Philippine Journal of Crop Science, 3, 78-89.

Cabrera-Bosquet, L., Albrizio, R., Luis Araus, J., \& Nogués, S. (2009). Photosynthetic capacity of field-grown durum wheat under different $\mathrm{N}$ availabilities: A comparative study from leaf to canopy. Environmental and Experimental Botany, 67, 145-152. http://dx.doi.org/10.1016/j.envexpbot.2009.06.004

Cao, T., Xie, P., Ni, L. Y., Zhang, M., \& Xu, J. (2009). Carbon and nitrogen metabolism of an eutrophication tolerative macrophyte, Potamogeton crispus, under $\mathrm{NH}_{4}{ }^{+}$stress and low light availability. Environmental 
and Experimental Botany, 66, 74-78. http://dx.doi.org/10.1016/j.envexpbot.2008.10.004

Cassman, K. G. (1999). Ecological intensification of cereal production systems: yield potential, soil quality, and precision agriculture. Proceedings of the National Academy of Sciences, USA 96, 5952-5959.

Correia, C. M., Moutinho Pereira, J. M., Coutinho, J. F., Björn, L. O., \& Torres-Pereira, J. M. G. (2005). Ultraviolet-B radiation and nitrogen affect the photosynthesis of maize: a Mediterranean field study. European Journal of Agronomy, 22, 337-347. http://dx.doi.org/10.1016/j.eja.2004.05.002

D’Andrea, K. E., Otegui, M. E., Cirilo, A. G., \& Eyhérabide, G. H. (2006). Genotypic variability in morphological and physiological traits among maize inbred lines-Nitrogen responses. Crop Science, 46, 1266-1276. http://dx.doi.org/10.2135/cropsci2005.07-0195

D’Andrea, K. E., Otegui, M. E., Cirilo, A. G., \& Eyhérabide, G. H. (2009). Ecophysiological traits in maize hybrids and their parental inbred lines: Phenotyping of responses to contrasting nitrogen supply levels. Field Crops Research, 114, 147-158. http://dx.doi.org/10.1016/j.fcr.2009.07.016

De Vos, C., Schat, H. M., De Waal, M. A., Vooijs, R., \& Ernst, W. (1991). Increased to copper-induced damage of the root plasma membrane in copper tolerant silene cucubalus. Plant Physiology, 82, 523-528. http://dx.doi.org/10.1111/j.1399-3054.1991.tb02942.x

Dordas, C. A., \& Sioulas, C. (2008). Safflower yield, chlorophyll content, photosynthesis, and water use efficiency response to nitrogen fertilization under rainfed conditions. Industrial Crops and Products, 27, 75-85. http://dx.doi.org/10.1016/j.indcrop.2007.07.020

Evans, J. R., \& Seemann, J. R. (1989). The allocation of protein nitrogen in the photosynthetic apparatus: cost, consequence and control. In W. Briggs (Ed.), Photosynthesis (pp. 183-205). Alan R. Liss Inc., New York.

Field, C., \& Mooney, H. A. (1986). The photosynthesis-nitrogen relationships in wild plants. In T. J. Givinish (Ed.), On the Economy of Form and Function. Cambridge University Press, Cambridge.

Foulkes, M. J., Hawkesford, M. J., Barraclough, P. B., Holdsworth, M. J., Kerr, S., Kightley, S., \& Shewry, P. R. (2009). Identifying traits to improve the nitrogen economy of wheat: Recent advances and future prospects. Field Crops Research, 114, 329-342. http://dx.doi.org/10.1016/j.fcr.2009.09.005

Gill, S. S., \& Tuteja, N. (2010). Reactive oxygen species and antioxidant machinery in abiotic stress tolerance in $\begin{array}{lllll}\text { crop plants. Plant Physiology and Biochemistry, 48, 909-930. } & \text {. }\end{array}$ http://dx.doi.org/10.1016/j.plaphy.2010.08.016

Goulding, K. W. T. (2004). Minimising losses of nitrogen from UK agriculture. Journal of the Royal Agricultural Society of England, 165, 1-11.

Hirel, B., \& Lea, P. J. (2001). Ammonium assimilation. In P. J. Lea, \& J. F. Morot-Gaudry (Eds.), Plant nitrogen (pp. 79-99). Berlin: Springer-Verlag.

Hirel, B., Le Gouis, J., Ney, B., \& Gallais, A. (2007). The challenge of improving nitrogen use efficiency in crop plants: towards a more central role for genetic variability and quantitative genetics within integrated approaches. Journal of Experimental Botany, 58, 2369-2387. http://dx.doi.org/10.1093/jxb/erm097

Huang, Z. A., Jiang, D. A., Yang, Y., Sun, J. W., \& Jin, S. H. (2004). Effects of nitrogen deficiency on gas exchange, chlorophyll fluorescence, and antioxidant enzymes in leaves of rice plants. Photosynthetica, 42, 357-64. http://dx.doi.org/10.1023/B:PHOT.0000046153.08935.4c

Kamkar, B., Daneshmand, A. R., Ghooshchi, F., Shiranirad, A. H., \& Safahani, L. A. R. (2011). The effects of irrigation regimes and nitrogen rates on some agronomic traits of canola under a semiarid environment. Agricultural Water Management, 98, 1005-1012. http://dx.doi.org/10.1016/j.agwat.2011.01.009

Koutroubas, S. D., Papakosta, D. K., \& Doitsinis, A. (2008). Nitrogen utilization efficiency of safflower hybrids and open-pollinated varieties under Mediterranean conditions. Field Crops Research, 107, 56-61. http://dx.doi.org/10.1016/j.fcr.2007.12.009

Lichtenthaler, H. K., \& Wellburn, A. R. (1983). Determinations of total carotenoids and chlorophyll a and b of leaf extracts in different solvents. Biochemical Society Transactions (London), 63, 591-592.

Liu, F. H. (2010). Sampling techniques in test of net photosynthetic rate of plant cultivars, an example from ramie (Boehmeria nivea (L.) Gaud.). Journal of Yunnan University, 32, 221-226.

Liu, R. X., Zhou, Z. G., Guo, W. Q., Chen, B. L., \& Oosterhuis, D. M. (2008). Effects of N fertilization on root development and activity of water-stressed cotton (Gossypium hirsutum L.) plants. Agricultural water 
management, 95, 1261-1270. http://dx.doi.org/10.1016/j.agwat.2008.05.002

Maity, S. K., Karmakar, S., \& Mukherjee, P. K. (2007). Response of ramie (Boehmeria nivea) cultivars to nutrient management and planting methods. Indian Journal of Agronomy, 52, 257-260.

Patra, P. S., \& Sinha, A. C. (2012). Integrated nitrogen management on growth, yield and economics of ramie (Boehmeria nivea L.). Indian Journal of Agricultural Research, 46, 365-368. Retrieved from http://www.arccjournals.com/indianjournals.com

Pompelli, M. F., Martins, S. C. V., Antunes, W. C., Chaves, A. R. M., \& DaMatta, F. M. (2010). Photosynthesis and photoprotection in coffee leaves is affected by nitrogen and light availabilities in winter conditions. Journal of Plant Physiology, 167, 1052-1060. http://dx.doi.org/10.1016/j.jplph.2010.03.001

Ramalho, J. C., Campos, P. S., Teixeira, M., \& Nunes, M. A. (1998). Nitrogen dependent changes in antioxidant system and in fatty acid composition of chloroplast membranes from Coffea Arabica L. plants submitted to high irradiance. Plant Science, 135, 115-124. http://dx.doi.org/10.1016/S0168-9452(98)00073-9

Rubio-Wilhelmi, M. M., Sanchez-Rodriguez, E., Rosales, M. A., Blasco, B., Rios, J. J., Romero, L., ... Ruiz, J. M. (2011). Effect of cytokinins on oxidative stress in tobacco plants under nitrogen deficiency. Environmental and Experimental Botany, 72, 167-173. http://dx.doi.org/10.1016/j.envexpbot.2011.03.005

Sánchez, E., Rivero, R. M., Ruiz, J. M., \& Romero, L. (2004). Changes in biomass, enzymatic activity and protein concentration in roots and leaves of green bean plants (Phaseolus vulgaris L. cv. Strike) under high $\mathrm{NH}_{4} \mathrm{NO}_{3}$ application rates. Scientia Horticulturae, $237-248$. http://dx.doi.org/10.1016/S0304-4238(03)00114-6

Sattelmacher, B., Horst, W. J., \& Becker, H. C. (1994). Factors that contribute to genetic variation for nutrient efficiency of crop plants. Zeitschrift für Pflanzenernährung und Bodenkunde, 157, 215-224. http://dx.doi.org/10.1002/jpln.19941570309

Sinclair, T. R., \& Vadez, V. (2002). Physiological traits for crop yield improvement in low N and P environments. Plant Soil, 245, 1-15. http://dx.doi.org/10.1023/A:1020624015351

Štajner, D., Kevrešan, S., Gasic, O., Mimica-Dukic, N., \& Zongli, H. (1997). Nitrogen and Azotobacter Chroococcum enhance oxidative tolerance in sugar beet. Biologia Plantarum, 39, 441-445. http://dx.doi.org/10.1023/A:1001000830977

Tatar, Ö., Ilker, E., Tonk, F. A., Aygün, H., \& Çaylak, Ö. (2010). Impact of different nitrogen and potassium application on yield and fiber quality of ramie (Boehmeria nivea). International Journal of Agriculture \& Bilogy, 12, 369-372. Retrieved from http://www.fspublishers.org

Upadhyaya, A., Sankhla, D., Davis, T. D., Sankhla, N., \& Smith, B. N. (1985). Effect of paclobutrazol on the activities of some enzymes of activated oxygen metabolism and lipid peroxidation in senescing soybean leaves. Journal of Plant Physiology, 121, 453-461. http://dx.doi.org/10.1016/S0176-1617(85)80081-X

Yang, X. H., Chen, X. Y., Ge, Q. Y., Li, B., Tong, Y. P., Li, Z. S., ... Lu, C. M. (2007). Characterization of photosynthesis of flag leaves in a wheat hybrid and its parents grown under field conditions. Journal of Plant Physiology, 164, 318-326. http://dx.doi.org/10.1016/j.jplph.2006.01.007

Yang, X. Y., Wang, X. F., Wei, M., Yang, F. J., \& Shi Q. H. (2010). Changes of nitrate reductase activity in cucumber seedlings in response to nitrate stress. Agricultural Sciences in China, 9, $216-222$. http://dx.doi.org/10.1016/S1671-2927(09)60086-9

Yao, X. Q., \& Liu, Q. (2006). Changes in morphological, photosynthetic and physiological responses of Mono Maple seedlings to enhanced UV-B and to nitrogen addition. Journal of Plant Growth Regulation, 50, 165-177. http://dx.doi.org/10.1007/s10725-006-9116-4

Zhang, L. X., Li, S. X., Zhang, H., \& Liang, Z. S. (2007). Nitrogen rates and water stress effects on production, lipid peroxidation and antioxidative enzyme activities in two maize (Zea mays L.) genotypes. Journal of Agronomy and Crop Science, 193, 387-397. http://dx.doi.org/10.1111/j.1439-037X.2007.00276.x

Zhang, X., Huang, G., Bian, X., \& Zhao, Q. (2013). Effects of root interaction and nitrogen fertilization on the chlorophyll content, root activity, photosynthetic characteristics of intercropped soybean and microbial quantity in the rhizosphere. Plant Soil and Environment, 2, 80-88.

Zhao, D., Raja Reddy, K., Vijaya Gopal Kakani, \& Reddy, V. R. (2005). Nitrogen deficiency effects on plant growth, leaf photosynthesis, and hyperspectral reflectance properties of sorghum. European Journal of Agronomy, 22, 391-403. http://dx.doi.org/10.1016/j.eja.2004.06.005 
Zhao, M., Lafitte, H. R., Sacks, E., Dimviuga, G., \& Botwright, A. T. L. (2008). Perennial O. sativa $\times$ O. rufipogon interspecific hybrids: I. Photosynthetic characteristics and their inheritance. Field Crops Research, 106, 203-213. http://dx.doi.org/10.1016/j.fcr.2007.12.005

\section{Copyrights}

Copyright for this article is retained by the author(s), with first publication rights granted to the journal.

This is an open-access article distributed under the terms and conditions of the Creative Commons Attribution license (http://creativecommons.org/licenses/by/3.0/). 